\title{
A New Statistical Approach to Assess Climate Variability in the White Bandama Watershed, Northern Côte d'Ivoire
}

\author{
Franck Zokou Yao ${ }^{1,2 *}$, Emmanuel Reynard ${ }^{2}$, Ismaïla Ouattara', Yao Alexis N'go1, \\ Jean-Michel Fallot ${ }^{2}$, Issiaka Savané ${ }^{1}$ \\ ${ }^{1}$ Faculty of Sciences and Environmental Management, University Nangui Abrogoua, Abidjan, Côte d'Ivoire \\ ${ }^{2}$ Institute of Geography and Sustainability, University of Lausanne, Lausanne, Switzerland \\ Email: ^f.zokou@yahoo.fr, ${ }^{\star}$ franck.yao@unil.ch, emmanuel.reynard@unil.ch, ismael2x@yahoo.fr, nyaoalexis@yahoo.fr, \\ jean-michel.fallot@unil.ch,savanei@hotmail.com
}

How to cite this paper: Yao, F.Z., Reynard, E., Ouattara, I., N'go, Y.A., Fallot, J.-M. and Savané, I. (2018) A New Statistical Approach to Assess Climate Variability in the White Bandama Watershed, Northern Côte d'Ivoire. Atmospheric and Climate Sciences, 8, 410-430.

https://doi.org/10.4236/acs.2018.84027

Received: August 29, 2018

Accepted: October 17, 2018

Published: October 20, 2018

Copyright (C) 2018 by authors and Scientific Research Publishing Inc. This work is licensed under the Creative Commons Attribution International License (CC BY 4.0).

http://creativecommons.org/licenses/by/4.0/

\begin{abstract}
The population of northern Côte d'Ivoire, especially in the white Bandama watershed, lives for majority in rural areas and depends on farming, which is mainly linked to climate variability. This study evaluates the trends within watershed's hydro-climatic variables and their level of significance over the period 1950-2000. The methodological approach consists in applying successively standardized indexes to detect trends and breaks in hydro-climatic long-term data. The Mann-Kendall statistical test lets us know the trends significance and the Kendall-Theil Robust Line test reveals their magnitude. The Student's t test underlines break years. Results show that although rainfall has decreased, this decline is not statistically significant. However, temperature and potential evapotranspiration have strongly rised and discharge was submitted to high decline. These changes in hydrometeorological variables appeared from 1970 to 1980 . This study is different from others conducted on climate variability in the northern Côte d'Ivoire by the methodological statistical framework implemented and the understanding of significance level of climate trends. Until now, authors used the standardized index to detect trends in hydro-climatic parameters. For this work, we added the Mann-Kendall statistical test to assess the significance level of these trends at $\alpha=5 \%$ and $10 \%$. Then, the Kendall-Theil statistical test was used to highlight the trends magnitude and the student's $t$ test to know the break years.
\end{abstract}

\section{Keywords}

Hydro-Climatic Trend, Statistical Tests, White Bandama Watershed 


\section{Introduction}

Climate change is becoming nowadays an important center of interest for the scientific community and also for the world population. Results from numerous researches confirm that no part of the planet is spared the hydro-climatic changes. In fact, this variability sometimes unpredictable of climate by the earth surface becomes recurring since the 1950s through rainfall deregulation, temperature increase and the occurrence of floods and droughts [1] [2]. In West Africa, drought conditions persistence has been observed during the last decades. The most recognized effect of climate interannual variability in this region is the severe drought that occurred during the 1970s and 1980s, with harmful consequences to population well-being and environment [3] [4]. Particularly, for the Sudano-Sahelian Africa, the rainfall deficit has been around 13\% and 27\% respectively during the 1970s and 1980s decades [5].

Some authors have examined rainfall trend in Côte d'Ivoire in order to understand the effects of climate variability. Results showed decreasing trend in precipitation and streamflow [6] [7] [8] [9]. The white Bandama watershed, in northern Côte d'Ivoire, belongs to the large Sudano-Sahelian area in West Africa. The watershed follows the general climatic trend observed in West Africa. Several studies have assessed the variability of climate conditions during the second part of the $20^{\text {th }}$ century [3] [10] [11]. They reached opposite findings. [12] suggested that the dryness has persisted through the 1990s with a few rainy years. In contrast, other studies [10] [13] showed that the Sahelian region has recorded a wet period since the beginning of the 1990s and consequences of this phenomenon are floods recorded in some cities [14] [15]. Unfortunately, most of these studies, both ancient and recent, are limited to the 2000s, because the availability of reliable data from measurement network has gradually decreased and ceased with the advent of political crisis occurred in the country in 2002. Moreover, statistical methods used, generally, are Pettitt, Buishand, Lee and Heghinian and Hubert statistical tests, implemented inside the Khronostat software [16]. In many areas around the world, studies undertaken about detecting trends and breaks in climate variables were made by using the Mann-Kendall and the Student's $t$ test [17]-[31].

The main goal of this paper is to (re)assess climate and hydrological trends which occurred in the white Bandama basin during the period 1950-2000 and to identify their magnitudes. A methodological framework including several statistical tests is implemented, using the standardized index method to detect trends in long term hydro-climatic data, the Mann-Kendall statistical test to know the level of significance of these trends, and the Kendall-Theil Robust Line statistical test to highlight their magnitude. Finally, the Student's t statistical test is used to determine the break years.

\section{Study Area}

The white Bandama basin in northern Côte d'Ivoire, is part of the Bandama riv- 
er basin (Figure 1). It is located between $9^{\circ} 22^{\prime}$ and $10^{\circ} 26^{\prime}$ North latitude and $5^{\circ} 00^{\prime}$ et $6^{\circ} 30^{\prime}$ West longitude. It covers Ferkessédougou, Ouangolodougou, Dikodougou, Korhogo, M’bengué, Sinematiali, Boundiali and Niakaramadougou cities. Its area is estimated to $12,750 \mathrm{Km}^{2}$ and population is around $1,607,497$ people. The population predominantly relies on agriculture and livestock breeding. Because of its strategic geographical position (borders with neighbouring countries), the watershed is the center of several economic and agricultural activities and has a high demographic growth [32].

The watershed river network includes the Bandama river and its tributaries (Solomougou, Lokpoho, Lafigué, Badenou). Its climate is classified as tropical regime of transition [33], with one rainy season from May to October and one drought season from November to April. The annual rainfall average is evaluated to $1230 \mathrm{~mm}$ (period 1950-2015). The runoff regime depends on the contrasted climatic regime. There is one period of low runoff from December to May. During that period, runoff generally is from subsurface return flow. The second runoff period is from June to November and represents the period of high flow. The most important floods occur in September with $300 \mathrm{~m}^{3} / \mathrm{s}$ on the 1962-1997 period [11]. Average relative humidity varies between 35\% and 79\%. Insolation values are spread over 160.6 hours (July) to 273.8 hours (January). Mean annual temperature is $26.6^{\circ} \mathrm{C}$. The highest values are obtained during the drought season with a peak in March $\left(29.5^{\circ} \mathrm{C}\right)$ and the lowest values are during rainy season with minimum in August $\left(24.7^{\circ} \mathrm{C}\right)$. All these climate information are from Korhogo synoptic station (SODEXAM, 2000) [34].

\section{Data and Methods}

\subsection{Hydro-Climatic Data Set}

Hydro-climatic data used in this work cover the entire study area at the monthly

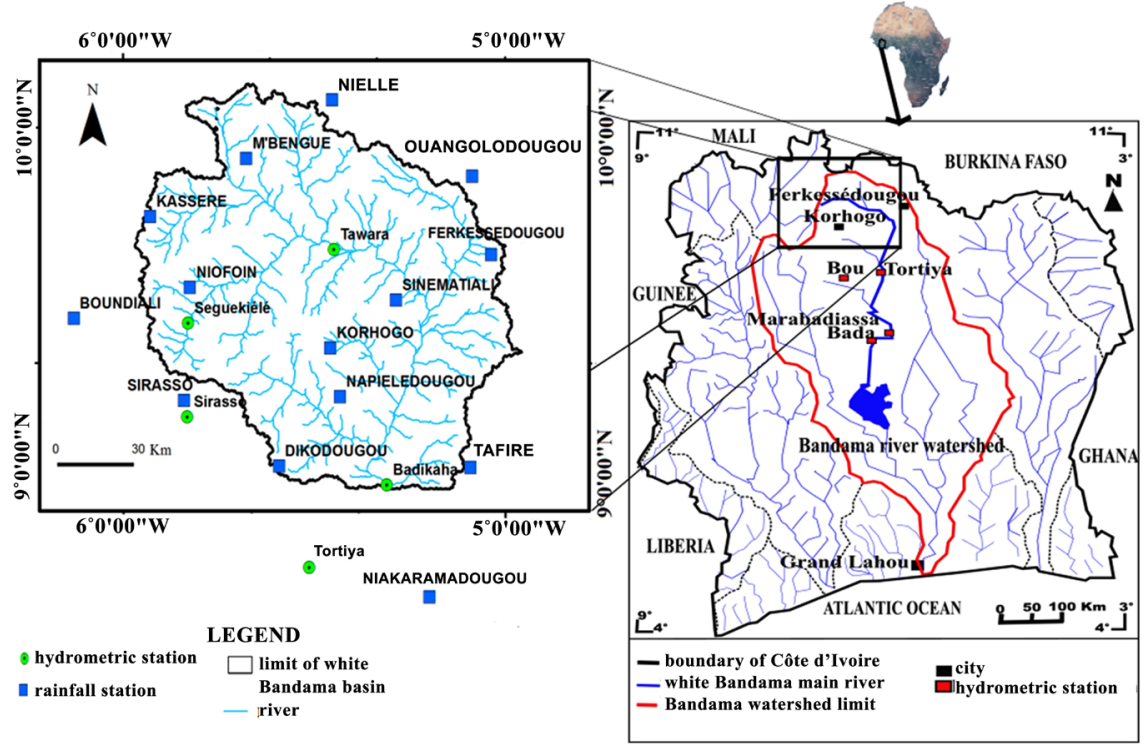

Figure 1. Location of the study area. 
scale and result from several entities. One part of climate data over the period 1950-2000 was provided by the Society of Development and Exploitation, Aeoroportuary, Aeronautic and Meteorology (SODEXAM): these are monthly rainfall at Boundiali, Ouangolodougou, Niofoin, Niellé, M’bengué, Sinématiali, and Korhogo stations (see Figure 1 for location, Table 1) and monthly temperature at Korhogo synoptic station. Monthly rainfall and temperature of Ferkessédougou station are from the meteorological station of the African Sugar Company of Côte d'Ivoire (SUCAF CI) and were recorded from 1944 to 2015. Korhogo synoptic station was used for temperature data and to estimate potential evapotranspiration by the Thornthwaite formula [35]. Taking into account, temperature and evaporation low spatial variability, information provided from Korhogo synoptic station are considered to be sufficient for the entire studied watershed [33].

Discharge data are from the network of measuring stations managed by the Ministry of Water and Forest. That data set is from Badikaha station located at the basin outlet and several surroundings stations: Tortiya, Tawara, Seguekiélé, and Sirasso (see Figure 1 for location, Table 2).

\subsection{Rainfall and Discharge Data Correction}

For this study rainfall data from Boundiali, Ferkessédougou, Korhogo and Ouangolodougou stations were used because they present a long time serie and fewgaps. When it was necessary to fill the gaps, data from other ten neighbour stations which operated during the missing months were used. The method of

Table 1. Rainfall stations used for this study.

\begin{tabular}{ccccc}
\hline Station & Period & $\begin{array}{c}\text { Number of } \\
\text { years with gaps }\end{array}$ & $\begin{array}{c}\text { Number of years } \\
\text { without observation }\end{array}$ & Full years (\%) \\
\hline Ferkessédougou & $1950-2015$ & 2 & 0 & 97 \\
Niellé & $1976-2000$ & 6 & 0 & 76 \\
Niofoin & $2000-2010$ & 0 & 0 & 100 \\
Sinématiali & $1976-1987$ & 6 & 0 & 50 \\
M'bengué & $1976-2000$ & 5 & 2 & 80 \\
Korhogo & $1944-2000$ & 3 & 0 & 95 \\
Niakaramadougou & $1950-1987$ & 3 & 0 & 92.10 \\
Ouangolo & $1950-2000$ & 4 & 2 & 92.15 \\
Boundiali & $1922-1997$ & 10 & 5 & 86.66 \\
Dikodougou & $1976-1987$ & 6 & 0 & 50 \\
Kasséré & $2000-2010$ & 0 & 0 & 100 \\
Napiélédougou & $1976-1987$ & 9 & 0 & 18.18 \\
Sirasso & $2000-2010$ & 0 & 0 & 100 \\
Tafiré & $1950-1987$ & 0 & 0 & 100 \\
\hline
\end{tabular}


Table 2. Discharge stations used for this study.

\begin{tabular}{ccccc}
\hline Station & Period & $\begin{array}{c}\text { Number of } \\
\text { years with gaps }\end{array}$ & $\begin{array}{c}\text { Number of years } \\
\text { without observation }\end{array}$ & Full years (\%) \\
\hline Badikaha & $1962-1997$ & 3 & 0 & 91.66 \\
Tortiya & $1960-1996$ & 7 & 15 & 59.45 \\
Sirasso & $1975-1996$ & 5 & 6 & 77.30 \\
Tawara & $1979-1996$ & 4 & 9 & 77.80 \\
Seguekiélé & $1974-1985$ & 2 & 0 & 83.33 \\
\hline
\end{tabular}

replacing the missing value by a weighted average of station trends monthly mean was also used. To fill gaps in discharge data got from Badikaha hydrometric station, the test of similar proportionality between hydrometric stations located on the same river was used. In fact, we applied the linear regression and correlation test between the main hydrometric Badikaha station and the neighbour discharge stations from Tortiya, Tawara, Seguekiélé, and Sirasso [36].

\subsection{Statistical Tests for the Analysis of Climate Trend}

The methodological framework is summarized in Figure 2. At first, in order to detect change in of database, the standardized variable statistical test was selected. Secondly, in order to understand trends in long time data, Mann-Kendall statistical test was used. Thirdly, the magnitude of trends was detected by calculating the slope of the line. Fourthly, change-point in hydro-climatic data were detected by the Student's t test. The Mann-Kendall and Student's t tests were processed with the computer software TREND [37]. To determine the magnitude of trends, we employed the line slope statistical test, by using the Kendall-Theil Robust Line (KTR Line-version 1.0) software developed by the US Geological survey [38]. These visual basic programs-available via www.toolkit.net.au (accessed on the 12/07/2018) are designed to facilitate statistical testing for trend, change and randomness in hydrological and other time series data. TREND has 12 statistical tests, based on the WMO/UNESCO Expert Workshop on Trend/Change detection and on the CRC for Catchment Hydrology publication Hydrological Recipes [39].

\subsubsection{Standardized Variable}

The standard or standardized variable is a positive or negative number of standard deviations by which the value of an observation, data point or variable is above or below the mean value of what is being observed or measured. Variables above the mean are positive, while variables below the mean are negative. The standardized variable of any climate variable can be defined by [40] [41]:

$$
N_{p}=\frac{X-\mu}{\sigma}
$$

where $N_{p}$ is the standardized variable, $X$ is the annual mean of the variable, $\mu$ is the annual mean of the serie $X$ and $\sigma$ is its standard deviation. 


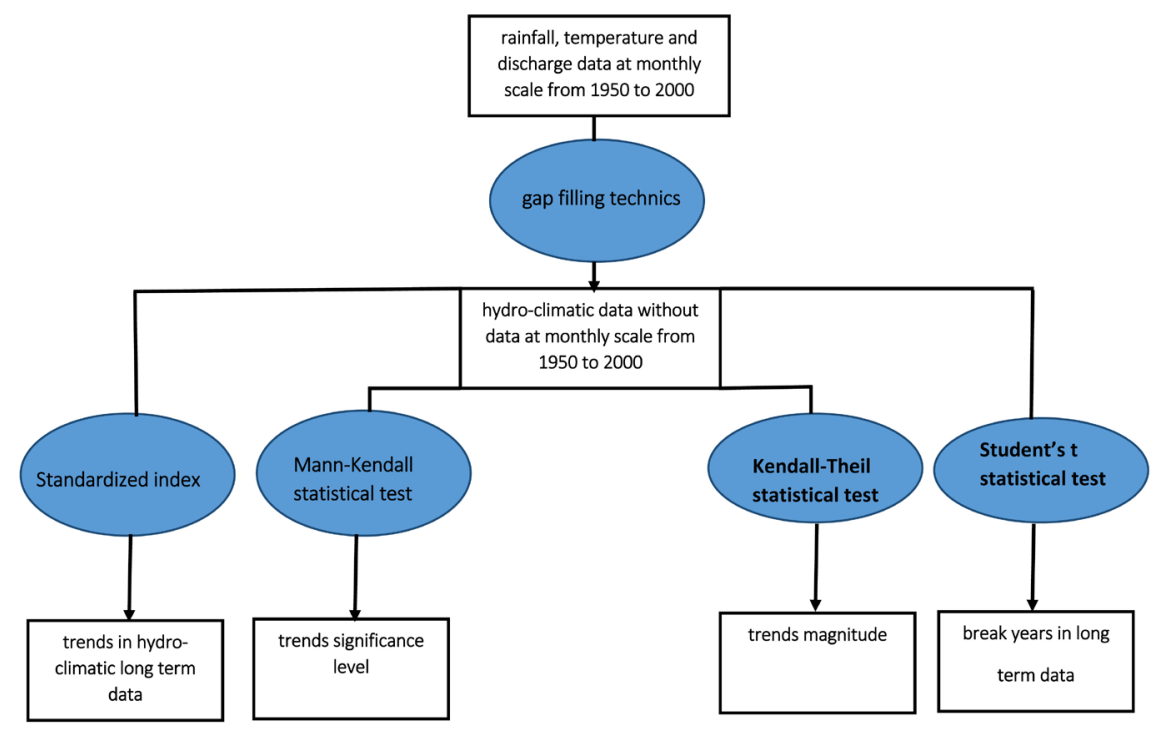

Figure 2. Study methodological framework.

\subsubsection{The Mann-Kendall Statistical Test}

The non-parametric Mann-Kendall test [37] [42] [43] [44] [45] [46] is commonly employed to quantify the significance of trends in series of environmental, climate or hydrological data. The null hypothesis, $\mathrm{H} 0$, is that there is no trend in data. The alternative hypothesis, $\mathrm{H} 1$, is that there is an increasing or decreasing trend. This method tests whether there is a trend in the time series data. It is a non-parametric test. The $\mathrm{n}$ time series values $\left(X_{1}, X_{2}, X_{3}, \ldots, X_{n}\right)$ are replaced by their ranks $\left(R_{1}, R_{2}, R_{3}, \ldots . ., R_{n}\right)$ (starting at 1 for the lowest up to n). The test statistic $S$ is:

$$
S=\sum_{i=1}^{n-1} \sum_{j=i+1}^{n} \operatorname{sgn}\left(R_{i}-R_{j}\right) \text { and } Z= \begin{cases}\frac{S-1}{\sqrt{\operatorname{var}(S)}}, & S>0 \\ 0, S=0 & S+1 \\ \frac{S+\sqrt{\operatorname{var}(S)}}{\sqrt{2}}, & S<0\end{cases}
$$

where sgn $(x)=1$ for $x>0$, sgn $(x)=0$ for $x=0$, sgn $(x)=-1$ for $x<0$.

Positive and negative values of $Z$ indicate increasing and decreasing trends respectively. Testing trends is done at the specific $\alpha$ significance level. When $\mathrm{p}$-value $<\alpha$, the null hypothesis is rejected and a significant trend exists in the time series. P-value is obtained from the standard normal distribution table. In this study, significance levels $\alpha=0.05$ and $\alpha=0.1$ were used. At the $5 \%$ significance level, the null hypothesis of no trend is accepted if p-value $>0.05$ and rejected if $\mathrm{p}$-value $<0.05$. At the $10 \%$ significance level, the null hypothesis of no trend is accepted if $\mathrm{p}$-value $>0.1$ and rejected if $\mathrm{p}$-value $<0.1[21]$.

\subsubsection{The Kendall-Theil Robust Line Statistical Test}

This test [38] allowed us to calculate parameters for robust, non-parametric estimates of linear-regression coefficients between two continuous variables. This 
method is based on a linear regression model which is written as:

$$
Y_{i}=m * X_{i}+b+e_{i} \text { for } i=1 \text { to } n
$$

where $X_{i}$ is the explanatory (independent, predictor, or $X$ ) variable for each data point ( $i) ; Y_{i}$ is the response (dependent, predicted, or $Y$ ) variable for each data point $(i) ; e_{i}$ is the residual error or uncertainty in the predicted $Y$ value for each data point $(i) ; m$ is the estimated slope; $b$ is the estimated intercept; $n$ is the number of $X Y$ data points in the sample.

The slope of the line $(m)$ is estimated as the median of all pairwise slopes between each pair of points in the data set. Each individual slope estimate $\left(m_{i j}\right)$ for the line connecting the $i$ th and $j$ th data point is calculated by use of the equation [47]-[52]:

$$
m_{i j}=\frac{\left(Y_{j}-Y_{i}\right)}{\left(X_{j}-X_{i}\right)} \text { for } i=1 \text { to } n-1 \text { and } j=2 \text { to } n
$$

\subsubsection{The Student's $t$ Statistical Test}

This method allows us to underline a change-point by checking whether the means in two different periods are different. The test assumes that the data are normally distributed. The Student's $t$ test statistic $t$ is (critical test statistic values for various significance levels can be obtained from Student's $t$ statistic tables) [53] [54] [55]:

$$
t=\frac{(\bar{X}-\bar{Y})}{S \sqrt{\frac{1}{n}+\frac{1}{m}}}
$$

where: $\bar{X}$ and $\bar{Y}$ are the means of the first and second periods respectively; $m$ and $n$ are the number of observations in the first and second periods respectively; $S$ is the sample standard deviation (of the entire $m$ and $n$ observations).

\section{Results}

\subsection{Interannual Variation in Hydro-Climatic Data}

By calculating the standardized index of climatic variables at different time scales, the evolution of annual rainfall within the basin was determined and a wet period, a dry period and a normal period could be highlighted (Table 3).

A wet period is considered when the indexes are negative and located below the $\mathrm{x}$-axis shown by zero and vice versa for a dry period. Thus, normal period is when indexes are distributed in a balanced way on either side of the $\mathrm{x}$-axis.

Results allowed us to show three main trends more or less similar at the annual scale. From 1950 to 1970, climate was characterized by wet conditions. For Ouangolodougou station, this wet period stopped in 1960. This wet trend is confirmed by rainfall index around +2 and mean annual discharge $\left(135 \mathrm{~m}^{3} / \mathrm{s}\right)$ greater than the long term serie mean annual discharge $\left(83 \mathrm{~m}^{3} / \mathrm{s}\right)$. Also the mean annual rainfall $(1500 \mathrm{~mm})$ is greater than the long-term mean annual rainfall (1200 
Table 3. Wet, dry and normal periods characterization from 1950 to 2000 .

\begin{tabular}{ccccc}
\hline & \multicolumn{4}{c}{ STATION } \\
\hline & Boundiali & Ferkessédougou & Korhogo & Ouangolodougou \\
\hline Wet period & $1950-1974$ & $1950-1970$ & $1950-1971$ & $1950-1960$ \\
Mean (mm) & 1680.75 & 1403.76 & 1392.67 & 1439.26 \\
Standard deviation & 357.45 & 235.95 & 261.22 & 447.85 \\
Normal Period & & & & $1961-1974$ \\
Mean (mm) & & & & 1119.21 \\
Standard deviation & & & & 146.27 \\
Dry period & $1975-2000$ & $1971-2000$ & $1972-2000$ & $1975-2000$ \\
Mean (mm) & 1265.13 & 1154.82 & 1135 & 1009.37 \\
Standard deviation & 186.68 & 145.25 & 166.28 & 194.30 \\
\hline
\end{tabular}

mm). Then, exceptionally, from 1961 to 1974, Ouangolodougou rainfall station recorded a normal period with rainfall index around 0. During the period with normal conditions, some dry years were observed (1958, 1961, and 1967) over the study basin. Finally, from 1970 to 2000 , climate was characterized by dry conditions, with low water, demonstrated by negative rainfall and discharge indexes. During that dry period, the mean annual rainfall was around $1000 \mathrm{~mm}$ and the mean annual discharge $\left(46 \mathrm{~m}^{3} / \mathrm{s}\right)$ was lower than the long-term annual mean discharge $\left(83 \mathrm{~m}^{3} / \mathrm{s}\right)$. The year 1990 was the rainiest at Korhogo station (Figure 3).

Temperature and potential evapotranspiration indexes are under 0 from 1950 to 1982 , demonstrating a colder period $\left(26.4^{\circ} \mathrm{C}\right)$ than the region annual mean $\left(26.7^{\circ} \mathrm{C}\right)$. Then, these two climate variables got an upward trend until 2000 and the mean annual temperature was $27^{\circ} \mathrm{C}$ (Figure 4).

The results obtained by the standardized index method underline that in the whole basin there has been a dry period since the 1970s, marked by rainfall and river discharge downward trend. At the opposite, an upward trend for temperature and potential evapotranspiration is observed since that period.

\subsection{Trend Significance and Magnitude in Hydro-Climatic Data}

The Mann-Kendall and Kendall-Theil Robust Line tests were applied to rainfall, temperature, potential evapotranspiration and discharge long-term data at annual, seasonal and monthly time scale (Table 4 and Table 5). The Mann-Kendall test showed that there is no significant statistical trend in annual rainfall for all the watershed's stations at level of significance $\alpha=5 \%$. At this same time scale, only Boundiali and Ferkessédougou stations have recorded a downward trend at level of significance $\alpha=10 \%$ with a weak magnitude around 0 . By contrast, the rainy season has declined across the basin, except at Ferkessédougou station, where there has not been a significant trend at the level of $\alpha=5 \%$ and a trend magnitude around 1. For the rainy season (from May to October), different 


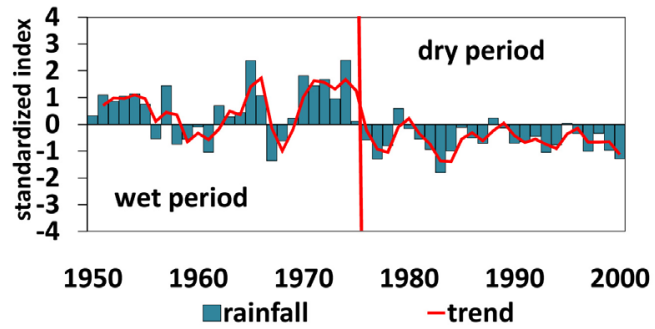

(a)

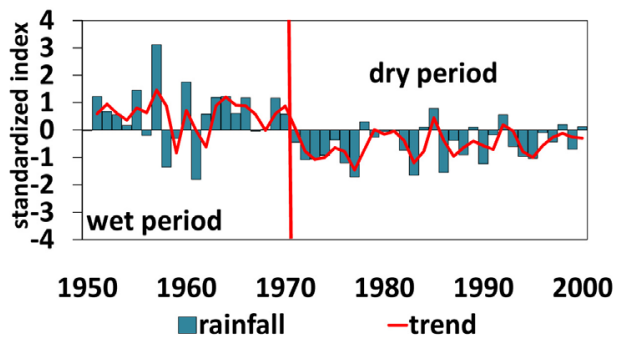

(c)

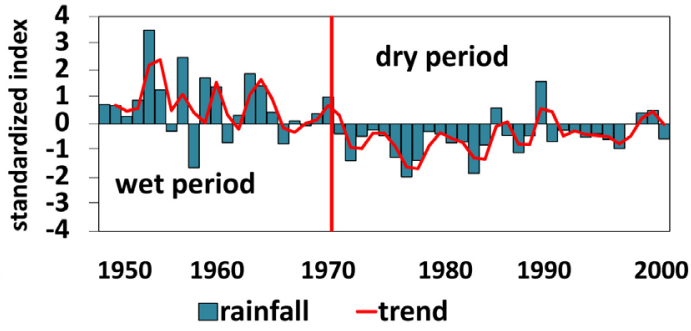

(b)

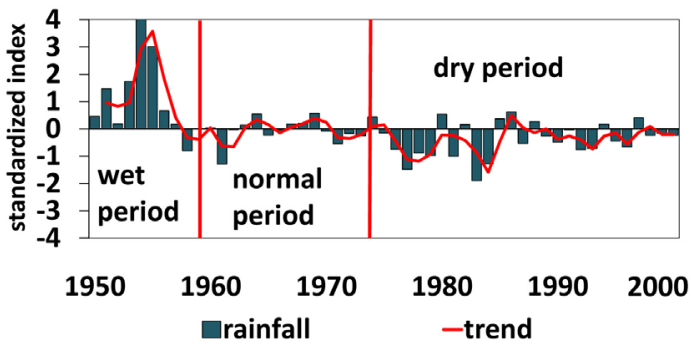

(d)

Figure 3. Rainfall interannual variation in the white Bandama basin at (a) Boundiali; (b) Ferkessédougou; (c) Korhogo and (d) Ouangolodougou station.

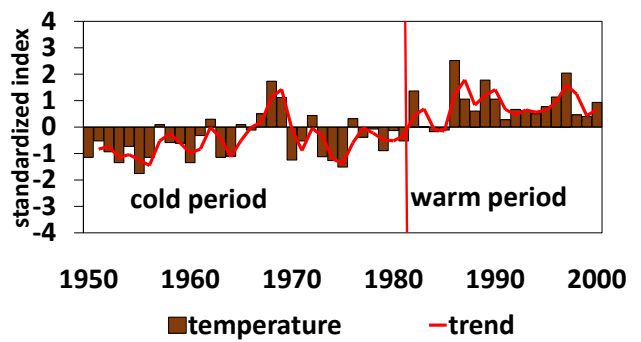

(a)

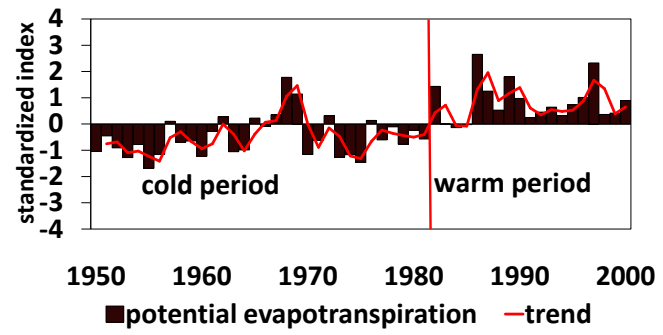

(b)

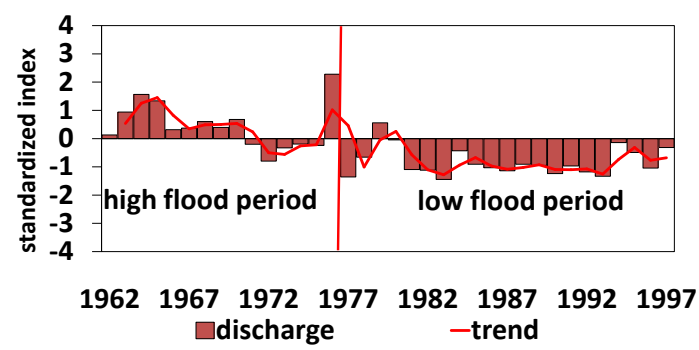

(c)

Figure 4. (a) Temperature; (b) Potential evapotranspiration; (c) Discharge interannual variations, respectively at Korhogo and Badikaha station. 
Table 4. Results of rainfall trends at annual, seasonal and monthly scale (1950-2000).

\begin{tabular}{|c|c|c|c|c|c|c|}
\hline \multirow[b]{2}{*}{ Stations } & \multirow[b]{2}{*}{ Variables } & \multirow[b]{2}{*}{$\mathrm{Z}_{\mathrm{MK}}$} & \multirow{2}{*}{\multicolumn{2}{|c|}{ p-value slope $(\mathrm{m})$}} & \multicolumn{2}{|c|}{ Result of trend test } \\
\hline & & & & & $\alpha=5 \%$ & $a=10 \%$ \\
\hline \multirow{8}{*}{ Boundiali } & Annual rainfall & -1.84 & 0.06 & -0.01 & No trend & Decline \\
\hline & $\begin{array}{l}\text { Rainy season } \\
\text { (May-October) }\end{array}$ & -2.89 & 0.00 & -0.20 & Decline & Decline \\
\hline & May & -2.90 & 0.00 & -0.02 & Decline & Decline \\
\hline & June & -2.61 & 0.00 & -1.52 & Decline & Decline \\
\hline & July & -2.60 & 0.00 & -1.50 & Decline & Decline \\
\hline & August & -1.57 & 0.11 & -1.97 & No trend & No trend \\
\hline & September & -2.16 & 0.03 & -1.85 & Decline & Decline \\
\hline & October & -1.41 & 0.15 & -1.00 & No trend & No trend \\
\hline \multirow{8}{*}{ Ferkessedougou } & Annual rainfall & -1.73 & 0.08 & 0.00 & No trend & Decline \\
\hline & $\begin{array}{l}\text { Rainy season } \\
\text { (May-October) }\end{array}$ & -1.67 & 0.09 & -0.08 & No trend & Decline \\
\hline & May & -1.32 & 0.18 & -0.52 & No trend & No trend \\
\hline & June & -1.37 & 0.16 & -0.86 & No trend & No trend \\
\hline & July & -0.43 & 0.66 & -0.32 & No trend & No trend \\
\hline & August & -2.40 & 0.01 & -2.65 & Decline & Decline \\
\hline & September & -1.73 & 0.08 & -1.00 & No trend & Decline \\
\hline & October & -1.74 & 0.08 & 0.40 & No trend & Decline \\
\hline \multirow{8}{*}{ Korhogo } & Annual rainfall & -1.10 & 0.26 & 0.00 & No trend & No trend \\
\hline & $\begin{array}{l}\text { Rainy season } \\
\text { (May-October) }\end{array}$ & -2.39 & 0.01 & -0.13 & Decline & Decline \\
\hline & May & -0.50 & 0.61 & -0.25 & No trend & No trend \\
\hline & June & -1.95 & 0.05 & -1.11 & No trend & Decline \\
\hline & July & 0.84 & 0.39 & 0.47 & No trend & No trend \\
\hline & August & -2.72 & 0.00 & -2.37 & Decline & Decline \\
\hline & September & -2.38 & 0.01 & -1.82 & Decline & Decline \\
\hline & October & -0.93 & 0.35 & -0.55 & No trend & No trend \\
\hline \multirow{8}{*}{ Ouangolodougou } & Annual rainfall & -1.41 & 0.15 & 0.00 & No trend & No trend \\
\hline & $\begin{array}{l}\text { Rainy season } \\
\text { (May-October) }\end{array}$ & -1.98 & 0.04 & -0.11 & Decline & Decline \\
\hline & May & -0.82 & 0.40 & -0.36 & No trend & No trend \\
\hline & June & -1.69 & 0.08 & -0.87 & No trend & Decline \\
\hline & July & -0.69 & 0.48 & -0.57 & No trend & No trend \\
\hline & August & -2.12 & 0.03 & -2.05 & Decline & Decline \\
\hline & September & -2.80 & 0.00 & 1.79 & Decline & Decline \\
\hline & October & 0.07 & 0.94 & 0.02 & No trend & No trend \\
\hline
\end{tabular}


Table 5. Results of temperature and potential evapotranspiration trends at annual, seasonal and monthly time scales (1950-2000).

\begin{tabular}{|c|c|c|c|c|c|c|}
\hline \multirow[b]{2}{*}{ Variables } & \multirow[b]{2}{*}{ Data Time Scale } & \multirow[b]{2}{*}{$\mathrm{Z}_{\mathrm{MK}}$} & \multirow[b]{2}{*}{ p-value } & \multirow[b]{2}{*}{ slope (m) } & \multicolumn{2}{|c|}{ Result of trend test } \\
\hline & & & & & $a=5 \%$ & $a=10 \%$ \\
\hline \multirow{8}{*}{$\begin{array}{c}\text { Temperature } \\
\text { at Korhogo Synoptic } \\
\text { Station }\end{array}$} & Annual rainfall & 2.97 & 0.00 & 0.00 & Increase & Increase \\
\hline & $\begin{array}{c}\text { Dry season } \\
\text { (November-April) }\end{array}$ & 4.28 & 0.00 & 0.00 & Increase & Increase \\
\hline & November & 0.87 & 0.38 & 0.00 & No trend & No trend \\
\hline & December & 4.13 & 0.00 & 0.03 & Increase & Increase \\
\hline & January & 4.74 & 0.00 & 0.05 & Increase & Increase \\
\hline & February & 4.31 & 0.00 & 0.04 & Increase & Increase \\
\hline & March & 4.37 & 0.00 & 0.03 & Increase & Increase \\
\hline & April & 2.56 & 0.01 & 0.00 & Increase & Increase \\
\hline \multirow{8}{*}{$\begin{array}{c}\text { Potential } \\
\text { Evapotranspiration } \\
\text { at Korhogo Synoptic } \\
\text { Station }\end{array}$} & Annual rainfall & 2.74 & 0.00 & 0.01 & Increase & Increase \\
\hline & $\begin{array}{c}\text { Dry season } \\
\text { (November-April) }\end{array}$ & 4.54 & 0.00 & 0.10 & Increase & Increase \\
\hline & November & 0.78 & 0.43 & 0.00 & No trend & No trend \\
\hline & December & 3.97 & 0.00 & 0.63 & Increase & Increase \\
\hline & January & 4.30 & 0.00 & 0.89 & Increase & Increase \\
\hline & February & 4.26 & 0.00 & 0.96 & Increase & Increase \\
\hline & March & 4.42 & 0.00 & 0.88 & Increase & Increase \\
\hline & April & 2.62 & 0.00 & 0.40 & Increase & Increase \\
\hline \multirow{8}{*}{$\begin{array}{c}\text { Discharge } \\
\text { at } \\
\text { Badikaha Hydrometric } \\
\text { Station }\end{array}$} & Annual rainfall & -8.98 & 0.00 & -0.20 & Decline & Decline \\
\hline & $\begin{array}{l}\text { Rainy season } \\
\text { (May-October) }\end{array}$ & -5.53 & 0.00 & -0.03 & Decline & Decline \\
\hline & May & -3.50 & 0.00 & -0.18 & Decline & Decline \\
\hline & June & -3.26 & 0.00 & -0.40 & Decline & Decline \\
\hline & July & -3.49 & 0.00 & -1.21 & Decline & Decline \\
\hline & August & -4.32 & 0.00 & -5.45 & Decline & Decline \\
\hline & September & -4.48 & 0.00 & -10.85 & Decline & Decline \\
\hline & October & -5.16 & 0.00 & -12.02 & Decline & Decline \\
\hline
\end{tabular}

trends were observed across the basin's stations. Rainfall in August, the rainiest month, has decreased at the level of significance $\alpha=5 \%$ and $\alpha=10 \%$. Nevertheless, at Boundiali station, there has been no trend for August rainfall and the magnitude was -1.95 . In Ferkessédougou station, by considering $\alpha=5 \%$ significance level, there is only a significant trend decline in August rainfall. At 10\% significance level, the decline trend concerns annual, rainy season, and August, September and October rainfall. The Sen's slope for August rainfall is the highest in the long term series $(-2.65)$. Stations of Korhogo and Ouangolodougou present the same trends in the annual precipitation, rainy season and August. 
These two stations have no significant trend in annual precipitation at $5 \%$ and $10 \%$ significance level but they record a same significant decline trend in the rainy season at both significance levels and almost the same Sen's slope value. It means -0.13 and -0.11 for Korhogo and Ouangolodougou respectively. At Korhogo synoptic station, temperature and potential evapotranspiration have an upward trend, except for November, in which, there is no significant trend the both significance level (5\% and 10\%).

Discharge is the only parameter which presents a unique trend at all time scales across the basin. It has a significant decline trend at $5 \%$ and $10 \%$ at the annual scale, for the rainy season and the rainy months. September and October discharge have the highest values for the Kendall-Theil Robust Line test, respectively -10.85 and -12.02 . According to the geographical location through the basin (Figure 5), rainfall has a trend or not at 5\% and $10 \%$ significance level for any time scale (annual, seasonal and monthly), while temperature and potential evapotranspiration have increased over the basin. At the basin outlet, located in the south, discharge showed a unique decline tendency at 5 and $10 \%$ significance level.

\subsection{Change-Year Detection in Hydrometeorological Series}

Student's t test showed several break points. A change point was revealed in the long-term precipitation data in 1970 for Ouangolodougou station, in 1971 for both Ferkessédougou and Korhogo stations, and in 1975 for Boundiali station (Table 6). Student's $t$ test statistic method also showed a break year in 1982 for both temperature and evaporation in the basin (Table 7).

Discharge data in the basin exhibit alternation from abundance to paucity.

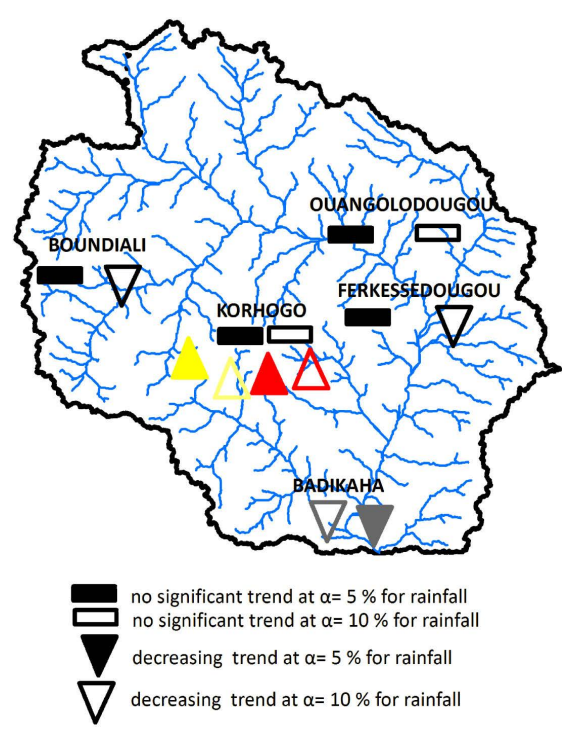

(a)

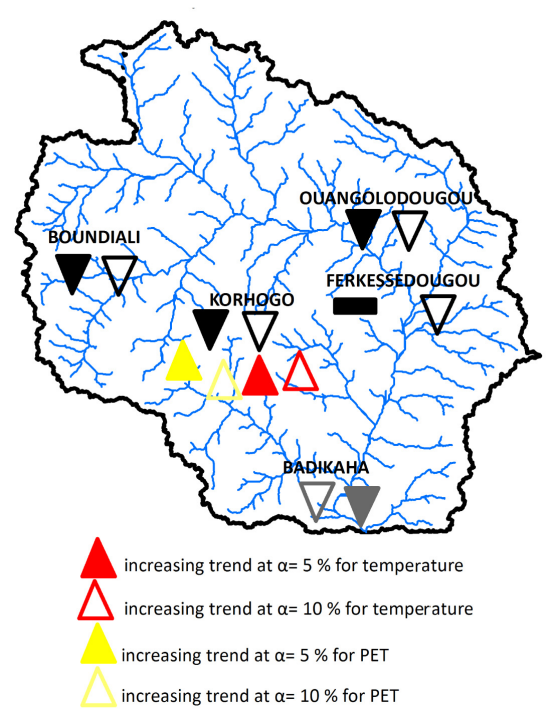

(b)

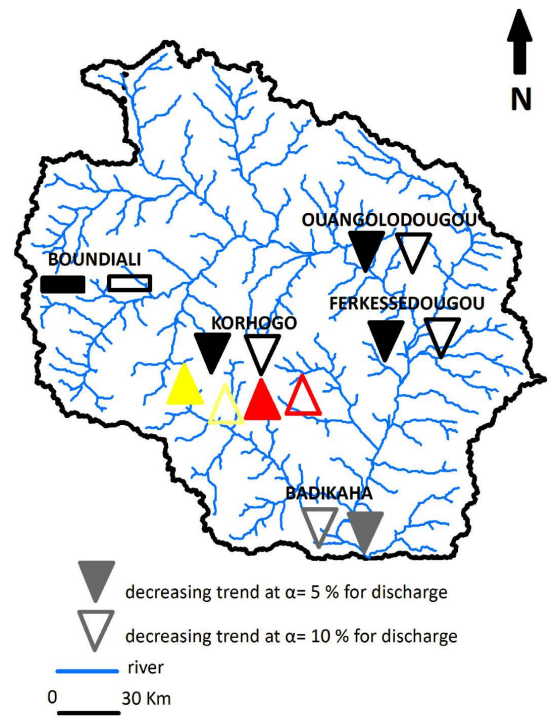

(c)

Figure 5. Spatial trends of hydro-climatic variables at annual (a); seasonal (b); monthly (c) time scale by the Mann-Kendall statistical test from 1950 to 2000 . 
Table 6. Detection of change-year in precipitation data at each station by Student's $t$ test over the period 1950-2000.

\begin{tabular}{cccccc}
\hline \multirow{2}{*}{ STATION } & \multirow{2}{*}{$t$} & p-value & \multicolumn{2}{c}{ RESULT } & \multirow{2}{*}{$\begin{array}{c}\text { YEAR OF } \\
\text { CHANGE }\end{array}$} \\
\cline { 4 - 5 } Boundiali & 3.13 & 0.00 & break & break & 1975 \\
Ferkessédougou & 2.37 & 0.01 & break & break & 1971 \\
Korhogo & 2.41 & 0.01 & break & break & 1971 \\
Ouangolodougou & 2.23 & 0.02 & break & break & 1970 \\
\hline
\end{tabular}

Table 7. Detection of change year of temperature, evaporation and discharge across the catchment by Student's $t$ test.

\begin{tabular}{cccccc}
\hline VARIABLE & \multirow{2}{*}{ p-value } & \multicolumn{2}{c}{ RESULT } & YEAR OF \\
\cline { 4 - 5 } & & & $\alpha=0.05$ & $\alpha=0.1$ & CHANGE \\
\hline $\begin{array}{c}\text { temperature at } \\
\text { Korhogo synoptic station }\end{array}$ & 2.972 & 0.00 & break & break & 1982 \\
$\begin{array}{c}\text { potential evapotranspiration } \\
\text { at Korhogo synoptic station }\end{array}$ & 2.742 & 0.00 & break & break & 1982 \\
$\begin{array}{c}\text { discharge at } \\
\text { Badikaha hydrometric station }\end{array}$ & -8.976 & 0.00 & break & break & 1977 \\
\hline
\end{tabular}

River flow tended to decrease over the period 1962-1997. The change point was recorded, by using Student's $t$ test statistic method, in 1977 (Table 7).

\section{Discussion}

The study firstly applied the standardized index method in order to determine the interannual variability of hydrometeorological parameters over the period 1950-2000. This test showed a decline trend for rainfall and discharge data, whereas temperature and potential evapotranspiration had an upward trend. A wet period was highlighted before the 1970s, a break/change period from the 1970 s to the 1980s, and a dry period from the break to the 1990s. Our findings are in agreement with several studies conducted in Côte d'Ivoire [11] [34] [56] [57] [58] [59] [60] and into Sahelian part of West Africa, that show a drought from the 1970s to 1993 [1] [3] [12] [61] [62] [63]. According to these authors, precipitation variations in the Sudano-sahelian region of West Africa, based on the rainfall standardized index, indicate that the 1970s and 1980s were dry due to fluctuations in the Intertropical Convergence Zone (ITCZ) shifting. The ITCZ is defined as a convergence zone of the northeasterly Harmattan winds that originate in the Sahara and the southwest monsoon flow that emanates from the Atlantic [64].

The second step of the analysis was to understand how the hydrometeorological trend could be considered in the study basin. Both the Mann-Kendall and Kendall-Theil Robust Line statistical tests were applied over the period from 1950 to 2000. Despite the severe drought during the 1970s and the 1980s, the 
annual rainfall downward trend, for the period 1950-2000, is not statistically significant. According to some authors, this situation could be explained as an annual rainfall recovery in West Africa during the last decade largely attributed to a climate shift in the mid-1990s to prevailing positive phases of the Atlantic Multidecadal Oscillation [13] [65] [66] [67]. To corroborate this assumption, they relate to floods that occurred in some urban areas of the Sahel. In fact, Korhogo and Bondoukou, two mains cities of the study basin, were devasted by torrential rainfalls in 2003 and 2006 [15]. Also, Niamey was deluged by heavy rainfalls in 1998, Dakar, Saint-Louis and Kaolack in Senegal were invaded by high floods in 1999 and again in 2000 [13] [14].

As the annual rainfall trend is not significant, on the contrary, trends in the rainy season and monthly rainfall during the rainy season are strongly decreasing at the level of significance $\alpha=5 \%$ and $\alpha=10 \%$. These results were also found by several authors, particularly, in Bangladesh [51], in stream flow distributions in Pacific Northwest of the United States [68], in East Africa [69], and in Nigeria [70]. They explain, on the one hand, that discrepancies between annual rainfall trends and rainy season could mean that the main factors of trends in annual and seasonal rainfall may be different. Also, effects of seasonal rainfall trend can be hidden by the overall trend of annual rainfall [21]. Different trends between annual rainfall and seasonal time scale could also be explained by the quality of data. Rainfall data from stations in the watershed contain gaps. The filling of these shortcomings can spoil the homogeneity of records.

Temperature and potential evapotranspiration significant rising trend at 5\% and $10 \%$ significance level for annual, seasonal and monthly scale highlight that the study area has got higher during the last decades. People in rural zones of West Africa support themselves mainly from subsistence level farming; hence, climate warming threatens them over the long term. Temperature rising across West Africa is described in many researches. According to [71], by using remote sensing data, temperature has increased of $0.5^{\circ} \mathrm{C}$ to $0.8^{\circ} \mathrm{C}$ from 1970 to 2010 , with a greater magnitude of change in the 1990s. Several reasons explain this temperature warming in the Sudano-sahelian area. At first, generally around the world, the concentration of anthropogenic greenhouse gas has increased in the atmosphere [72] [73] [74]. Secondly, anthropogenic pressure is becoming higher. Especially, across sub-Sahara Africa, [75] showed that from 1975 to 2000, there has been a $57 \%$ increase in agricultural areas and 15\% increase in barren (largely desert) areas was accompanied by a $16 \%$ decrease in total forest cover.

Discharge trend was estimated only at the watershed outlet because of homogenous and long-term data lacks. Results display a significant decline trend over the study period at annual, seasonal time scale and during the rainy season. The statistical tests were significant at the level of $\alpha=5 \%$ and $10 \%$. Moreover, a break year was detected in 1977, which separates discharge long-term data according to two different periods by annual module: $100 \mathrm{~m}^{3} / \mathrm{s}$ over the wet period before 1977 and $35 \mathrm{~m}^{3} / \mathrm{s}$ over the dry period after that year. Research conducted by [11] 
at Tortiya hydrometric station (see Figure 1 for location) also showed a discharge decline, with a change year in 1974 [4]. Also found a decline in the Baniriver discharge in Mali for the period 1950-2000. Break years found with the Student's $t$ statistical test in hydrometeorological data at annual scale are in compliance with other authors' studies about climate variability across Côte d'Ivoire [36] [76] [77] [78]. These breaks coincide with the period from 1970s to 1980s, marked by a severe drought in West Africa. Spatial distribution of hydro-climatic stations displaying upward, downward and no trend at annual, seasonal and monthly time scale from 1950 to 2000 is presented in Figure 5. The synoptic station in the center zone of the studied area presents an upward trend at the significance level of $5 \%$ and $10 \%$ for temperature and potential evapotranspiration. Also, the flow station, in the southern zone (outlet) of the studied watershed records a downward trend at the significance level of $5 \%$ and $10 \%$ for river discharge. Lastly, the very small number of rainfall stations and their weak geographical distribution do not allow concluding about specific regional rainfall trends across the watershed.

The discharge declining trend is stronger than the rainfall trend. Consequently, we conclude that discharge tendency is only partly influenced by precipitation trend. Hence, human activities and high potential evapotranspiration could be the main causes of discharge decline. Similar results were found in other areas of the world [79] [80] [81], for instance in China. Discharge decline due to anthropogenic pressure could be explained by the large number of projects carried out across the study area in the 1980s and 1990s for agricultural activities, water supply, fight against waterborne diseases, and development of livestock [7] [82]. These development programmes allowed slowing down the exodus of young people and rural inhabitants towards big and developed cities of Côte d'Ivoire by improving their life level but the disadvantage was the increase of human pressure on water resources and environment.

\section{Conclusion and Perspectives}

The objective of this study about the white Bandama basin in the northern Côte d'Ivoire was focused on hydro-climatic trends and their magnitude. A methodological framework including several statistical tests was implemented: 1) the standardized index allowed us to identify trends into hydro-climatic data; 2) the non-parametric Mann-Kendall test was used to quantify the significance of trends in climate variable data; 3 ) the Kendall-Theil Robust Line statistical test permitted us to know the magnitude of trends; 4 ) and the Student's $t$ test allowed us to detect break/change years in climate and hydrological data. The downward trend in annual rainfall for the period 1950-2000 is not statistically significant, while temperature and potential evapotranspiration have registered a significant increasing trend. Spatially, the Badikaha hydrometric station in the basin outlet in the southern zone was submitted to significant decreasing trend in discharge. Korhogo synoptic station in the center of the study area has displayed significant 
increasing trend for temperature and potential evapotranspiration. All these changes in climate and hydrological data started from the 1970s to the 1980s. We conclude that anthropogenic pressure and high evapotranspiration were the main driving factors of discharge downward trend during the period 1950-2000.

\section{Acknowledgements}

This research was supported by the Swiss Confederation through the excellence scholarship for foreign students obtained by Franck Zokou YAO.

\section{Conflicts of Interest}

The authors declare no conflicts of interest regarding the publication of this paper.

\section{References}

[1] Dai, A., Lamb P.J., Trenberth, E.K., Hulme, M., Jones, D.P. and Xie, P. (2004) The Recent Sahel Drought Is Real. International Journal of Climatology, 24, 1323-1331. https://doi.org/10.1002/joc.1083

[2] Ly, M., Traoré, B.S., Alhassane, A. and Sarr, B. (2013) Evolution of Some Observed Climate Extremes in the West African Sahel. Weather Climate and Extreme, 1, 19-25.

[3] Paturel, J.E., Servat, E. and Delattre, O.M. (1998) Analyse de séries pluviométriques de longue durée en Afrique de l'Ouest et centrale non sahélienne dans un contexte de variabilité climatique. Hydrological Sciences Journal, 43, 937-945. https://doi.org/10.1080/02626669809492188

[4] Mahé, G., Olivry, J.C., Dessouassi, R., Orange, D., Bamba, F. and Servat, E. (2000) Relations eaux de surface-eaux souterraines d'une rivière tropicale au Mali. Comptes Rendus Académie des Sciences. Paris, Sciences de la terre et des planètes, 330, 686-692.

[5] Bricquet, J.P., Bamba, F., Mahe, G., Toure, M. and Olivry, J.C. (2000) Evolution récente des ressources en eau de l'Afrique Atlantique. Revue des Sciences de l'Eau, 10, 321-337. https://doi.org/10.7202/705282ar

[6] Aka, A.A., Lubes, H., Masson, M., Servat, E., Paturel, J.E. and Kouame, B. (1995) Analyse de l'évolution temporelle des écoulements en Côte d'Ivoire. Approche statistique et caractérisation des phénomènes, Premier atelier scientifique du projet Friend AOC, Cotonou.

[7] Servat, E. and Dezetter, A. (1992) Modélisation de la relation pluie-débit et estimation des apports en eau dans le nord-ouest de la Côte d'Ivoire. Hydrologie Continentale, 7, 129-142.

[8] Brou, T., Servat, E. and Paturel, J.E. (1998) Activités humaines et variabilité climatique: Cas du sud forestier ivoirien, In Conférence internationale ABIDJAN 98-Water Resources Variability in Africa during the 20th Century, Abidjan, Côte d'Ivoire, 16-18 Novembre 1998, IAHS Publications, 252, 365-373.

[9] Goula, B.T.A., Savane, I., Konan, B., Fadika, V. and Kouadio, G.B. (2006) Impact de la variabilité climatique sur les ressources hydriques des bassins de N'Zo et N'Zi en Côte d'Ivoire (Afrique tropicale humide). VertigO, 1, 1-12.

https://doi.org/10.4000/vertigo.2038

[10] Nicholson, S.E., Some, B. and Kone, B. (2000) An Analysis of Recent Rainfall Con- 
ditions in West Africa, including the Rainy Season of the 1997 El Niño and the 1998 La Niña Years. Journal of Climate, 13, 2628-2640. https://doi.org/10.1175/1520-0442(2000)013<2628:AAORRC >2.0.CO;2

[11] Soro, T.D., Kouakou, D.B., Kouassi, A.E., Soro, G., Kouassi, M.A., Kouadio, E.K., et al. (2013) Hydroclimatologie et dynamique de l'occupation du sol du bassin versant du Haut Bandama à Tortiya (Nord de la Côte d'Ivoire). VertigO, 13, 3. https://doi.org/10.4000/vertigo.14468

[12] L’Hôte, Y., Mahé, G., Somé, B. and Triboulet, P.J. (2002) Analysis of a Sahelian Annual Index from 1896 to 2000; the Drought Continues. Hydrological Sciences Journal, 47, 563-572. https://doi.org/10.1080/02626660209492960

[13] Ozer, P., Erpicum, M., Demarée, G. and Vandiepenbeeck, M. (2003) The Sahelian Drought May Have Ended during the 1990s. Hydrological Sciences Journal, 48, 489-492. https://doi.org/10.1623/hysj.48.3.489.45285

[14] Sene, S. and Ozer, P. (2002) Evolution pluviométrique et relation inondationsévènements pluvieux au Sénégal. Bulletin de la Société de Géographie de Liège, 42, 27-33.

[15] Boko-Koiadia, A.N.N., Guéladio, C., Brama, K. and Dedy, S. (2016) Variabilité climatique et changements dans l'environnement à Korhogo en Côte d'Ivoire: Mythes ou réalités? European Scientific Journal, 12, 158-176.

[16] Institut de recherche pour le développement (IRD) (1998) KhronoStat Version 1.0. Logiciel, IRD. http://www.hydrosciences.org/spip.php?article1000

[17] Madsen, H., Lawrence, D., Lang, M., Martinkova, M. and Kjeldsen, T.R. (2014) Review of Trend Analysis and Climate Change Projections of Extreme Precipitation and Floods in Europe. Journal of Hydrology, 519, 3634-3650.

https://doi.org/10.1016/j.jhydrol.2014.11.003

[18] Ouarda, T.B.M.J., Chiron, C., Kumar, N.K., Marpu, R.P., Ghedira, H., Molini, A. and Khayal, I. (2014) Evolution of the Rainfall Regime in the United Arab Emirates. Journal of Hydrology, 514, 258-270. https://doi.org/10.1016/j.jhydrol.2014.04.032

[19] Xia, U., Zeng, S., Du, H. and Zhan, C. (2014) Quantifying the Effects of Climate Change and Human Activities on Runoff in the Water Source Area of Beijing, China. Hydrological Sciences Journal, 59, 1794-1807. https://doi.org/10.1080/02626667.2014.952237

[20] Jones, R.J., Schwartz, S.J., Ellis, N.K., Hathawayd, M.J. and Jawdy, M.C. (2013) Temporal Variability of Precipitation in the Upper Tennessee Valley. Journal of Hydrology: Regional Studies, 3, 125-138.

[21] Onyutha, C., Tabari, H., Taye, T.M., Nyandwaro, N.G. and Willems, P. (2015) Analyses of Rainfall Trends in the Nile River Basin. Journal of Hydro Environmental Resources, 13, 36-51. https://doi.org/10.1016/j.jher.2015.09.002

[22] Buendia, C., Batalla, J.R., Sabater, S., Palau, A. and Marcé, R. (2016) Runoff Trends Driven by Climate and Afforestation in a Pyrenean Basin. Land Degradation and Development, 27, 823-838. https://doi.org/10.1002/ldr.2384

[23] Huang, Z., Yang, H. and Yang, D. (2016) Dominant Climatic Factors Driving Annual Runoff Changes at the Catchment Scale across China. Hydrology Earth System Sciences, 20, 2573-2587. https://doi.org/10.5194/hess-20-2573-2016

[24] Lutz, R.S., Mallucci, S., Diamantini, E., Maloney, B., Bellin, A. and Merz, R. (2016) Hydroclimatic and Water Quality Trends across Three Mediterranean River Basins. Sciences of the Total Environment, 571, 1392-1406. https://doi.org/10.1016/j.scitotenv.2016.07.102

[25] Qin, W., Guo, Q., Zuo, C., Shan, Z., Ma, L. and Sun, G. (2016) Spatial Distribution 
and Temporal Trends of Rainfall Erosivity in Mainland China for 1951-2010. Catena, 147, 177-186. https://doi.org/10.1016/j.catena.2016.07.006

[26] Faye, C. (2017) Variabilité et tendances observées sur les débits moyens mensuels, saisonniers et annuels dans le bassin de la Falémé (Sénégal). Hydrological Sciences Journal, 62, 259-269. https://doi.org/10.1080/02626667.2014.990967

[27] Ndehedehe, E.C., Awange, L.J., Kuhn, M., Agutu, O.N. and Fukuda, Y. (2017) Analysis of Hydrological Variability over the Volta River Basin Using In-Situ Data and Satellite Observations. Journal of Hydrology. Regional Studies, 12, 88-110.

[28] Oguntunde, G.P., Abiodun, J.B. and Lischeid, G. (2017) Impacts of Climate Change on Hydro-Meteorological Drought over the Volta Basin, West Africa. Global Planet Change, 155, 121-132. https://doi.org/10.1016/j.gloplacha.2017.07.003

[29] Kahsay, D.K., Pingale, M.S. and Hatiye, D.S. (2018) Impact of Climate Change on Groundwater Recharge and Base Flow in the Sub-Catchment of Tekeze Basin, Ethiopia. Groundwater Sustainable Development, 6, 121-133. https://doi.org/10.1016/j.gsd.2017.12.002

[30] Pandey, K.B. and Khare, D. (2018) Identification of Trend in Long Term Precipitation and Reference Evapotranspiration over Narmada River Basin (India). Global Planet Change, 161, 172-182. https://doi.org/10.1016/j.gloplacha.2017.12.017

[31] Yaghmaei, H., Sadeghi, H.S., Moradi, H. and Gholamalifard, M. (2018) Effect of Dam Operation on Monthly and Annual Trends of Flow Discharge in the Qom Rood Watershed, Iran. Journal of Hydrology, 557, 254-264. https://doi.org/10.1016/j.jhydrol.2017.12.039

[32] Institut National de la Statistique (2014) Synthèse des résultats définitifs du Recensement Général de la Population et de l'Habitat. INS, Abidjan, 37 p.

[33] Dezetter, A. (1991) Modélisation globale de la relation pluie débit. Application en zone de savanes soudanaises (Nord-Ouest de la Côte d'Ivoire). Thèse de Doctorat, Université de Montpellier II, Montpellier.

[34] Kouakou, E., Koné, B., N’Go, A., Cissé, G., Ifejika, S.C. and Savané, I. (2014) Groundwater Sensitivity to Climate Variability in the White Bandama Basin, Ivory Coast. SpringerPlus, 3, 226. https://doi.org/10.1186/2193-1801-3-226

[35] Thornthwaite, C.W. (1948) An Approach toward a Rational Classification of Climate. Geogrophy Review, 38, 55-99.

[36] Ardoin, B.S. (2004) Variabilité hydroclimatique et impacts sur les ressources en eau de grands bassins hydrographiques en zone soudano-sahélienne. Thèse de Doctorat, Université de Montpellier II, Montpellier.

[37] Kundzewicz, Z.W. and Robson, A. (2000) Detecting Trend and Other Changes in Hydrological Data. World Meteorological Organization, Geneva, 157.

[38] Granato, G.E. (2006) Kendall-Theil Robust Line (KTRLine-Version 1.0) a Visual Basic Program for Calculating and Graphing Robust Nonparametric Estimates of Linear-Regression Coefficients between Two Continuous Variables: Techniques and Methods. US Geological Survey, Virginia, 37.

[39] Grayson, R.B., Argent, R.M., Nathan, R.J., McMahon, T.A. and Mein, R.T. (1996) Hydrological Recipes: Estimation Techniques in Australian Hydrology. Cooperative Research Centre for Catchment Hydrology, Sydney, 125.

[40] Duhan, D. and Pandey, A. (2013) Statistical Analysis of Long Term Spatial and Temporal Trends of Precipitation during 1901-2002 at Madhya Pradesh, India. Atmospheric Research, 122, 136-149. https://doi.org/10.1016/j.atmosres.2012.10.010

[41] Da Silva, M.R., Santos, G.A.C., Moreira, M., Corte-Real, J., Silva, L.C.V. and Me- 
deiros, C.I. (2015) Rainfall and River Flow Trends Using Mann-Kendall and Sen's Slope Estimator Statistical Tests in the Cobres River Basin. Natural Hazard, 77, 1205-1221. https://doi.org/10.1007/s11069-015-1644-7

[42] Murillo, R.J.C., Zobrist, J. and Filella, M. (2014) Temporal Trends in Organic Carton Content in the Main Swiss Rivers, 1974-2010. Sciences of the Total Environment, 502, 206-217.

[43] Sagarika, S., Kalra, A. and Ahmad, S. (2014) Evaluating the Effect of Persistence on Long-Term Trends and Analyzing Step Changes in Streamflows of the Continental United States. Journal of Hydrology, 513, 36-53. https://doi.org/10.1016/j.jhydrol.2014.05.002

[44] Ficklin, D.L., Robeson, S.M. and Knouft, J.H. (2016) Impacts of Recent Climate Change on Trends in Baseflow and Stormflow in United States Watersheds. Geophysical Research Letters, 43, 5079-5088. https://doi.org/10.1002/2016GL069121

[45] Liuzzo, L., Enrico, B.E., Sammartano, V. and Freni, G. (2017) Long-Term Temperature Changes in Sicily, Southern Italy. Atmospheric Research, 198, 44-55. https://doi.org/10.1016/j.atmosres.2017.08.007

[46] Montaldo, N. and Sarigu, S. (2017) Potential Links between the North Atlantic Oscillation and Decreasing Precipitation and Runoff on a Mediterranean Area. Journal of Hydrology, 553, 419-437. https://doi.org/10.1016/j.jhydrol.2017.08.018

[47] Gocic, M. and Trajkovic, S. (2013) Analysis of Changes in Meteorological Variables Using Mann-Kendall and Sen's Slope Estimator Statistical Tests in Serbia. Global Planet Change, 100, 172-182. https://doi.org/10.1016/j.gloplacha.2012.10.014

[48] Sayemuzzaman, M., Jha, K.M., Mekonnen, A. and Schimmel, A.K. (2014) Subseasonal Climate Variability for North Carolina, United States. Atmospheric Research, 145-146, 69-79. https://doi.org/10.1016/j.atmosres.2014.03.032

[49] Taxak, K.A., Murumkar, R.A. and Arya, S.D. (2014) Long Term Spatial and Temporal Rainfall Trends and Homogeneity Analysis in Wainganga Basin, Central India. Weather Climate Extreme, 4, 50-61. https://doi.org/10.1016/j.wace.2014.04.005

[50] Lopez, B., Baran, N. and Bourgine, B. (2015) An Innovative Procedure to Assess Multi-Scale Temporal Trends in Groundwater Quality: Example of the Nitrate in the Seine-Normandy Basin, France. Journal of Hydrology, 522, 1-10. https://doi.org/10.1016/j.jhydrol.2014.12.002

[51] Bari, H.S., Rahman, U.T.M., Hoque, A.M. and Hussain, M.M. (2016) Analysis of Seasonal and Annual Rainfall Trends in the Northern Region of Bangladesh. Atmospheric Research, 176-177, 148-158. https://doi.org/10.1016/j.atmosres.2016.02.008

[52] Moore, W.T. (2017) On the Temporal and Spatial Characteristics of Tornado Days in the United States. Atmospheric Research, 184, 56-65. https://doi.org/10.1016/j.atmosres.2016.10.007

[53] Rodionov, S.A. (2015) Sequential Method of Detecting Abrupt Changes in the Correlation Coefficient and Its Application to Bering Sea Climate. Climate, 3, 474-491. https://doi.org/10.3390/cli3030474

[54] Ross, G.J. (2015) Parametric and Nonparametric Sequential Change Detection in R: The CPM Package. Journal of Statistic Software, 66, 1-20.

[55] Hosseini, M. and Kerachian, R. (2017) A Data Fusion-Based Methodology for Optimal Redesign of Groundwater Monitoring Networks. Journal of Hydrology, 552, 267-282. https://doi.org/10.1016/j.jhydrol.2017.06.046

[56] Saley, M.B. (2003) Système d’information hydrogéologique à référence spatiale, 
discontinuités pseudo-images, et cartographie thématique des ressources en eau de la région semi-montagneuse de Man (Ouest de la Côte d'Ivoire). Thèse unique de doctorat, Université de Cocody, Abidjan.

[57] Kouakou, K.E., Goula, B.T.A. and Savané, I. (2007) Impacts de la variabilité climatique sur les ressources en eau de surface en zone tropicale humide: Cas du bassin versant transfrontalier de la Comoé (Côte d'Ivoire-Burkina Faso). European Journal of Scientific Research, 16, 31-43.

[58] Adja, M.G., Jourda, J.P.R., Kouamé, K.J., Diby, B., Koffi, F.K., Saley, B.M., et al. (2009) Cartographie quantitative de la dynamique de l'assèchement des cours d'eau du bassin versant de la Bagoé par analyse diachronique d'images ETM + de Landsat (milieu soudano-sahélien de Côte d'Ivoire). European Journal of Scientific Research, 27, 417-425.

[59] Kanohin, F., Saley, M.B. and Savané, I. (2009) Impacts de la variabilité climatique sur les ressources en eau et les activités humaines en zone tropicale humide: Cas de la région de Daoukro en Côte d'Ivoire. European Journal of Scientific Research, 26, 209-222.

[60] Soro, D.T., Soro, N., OGA, M.S., Lasm, T., Soro, G., Ahoussi, E.K., et al. (2011) La variabilité climatique et son impact sur les ressources en eau dans le degré carré de Grand-Lahou (Sud-Ouest de la Côte d'Ivoire). Physio-Géo, 5, 55-73.

https://doi.org/10.4000/physio-geo.1581

[61] Servat, E., Paturel, J.E., Lubes-Niel, H., Kouame, B., Masson, J.M., Travaglio, M., et al. (1999) De différents aspects de la variabilité de la pluviométrie en Afrique de l'ouest et centrale non sahélienne. Revue des Sciences de l'Eau, 12, 363-387. https://doi.org/10.7202/705356ar

[62] Le Barbé, L., Lebel, T. and Tapsoba, D. (2002) Rainfall Variability in West Africa during the Years 1950-90. Journal of Climate, 15, 187-202. https://doi.org/10.1175/1520-0442(2002)015<0187:RVIWAD >2.0.CO;2

[63] Flaounas, E., Janicot, S., Bastin, S. and Roca, R. (2012) The West Africa Monsoon Onset in 2006: Sensitivity to Surface Albedo, Orography, SST and Synoptic Scale Dry-Air Intrusions Using WRF. Climate Dynamics, 38, 685-708. https://doi.org/10.1007/s00382-011-1255-2

[64] Nicholson, S.E. (2013) The West African Sahel: A Review of Recent Studies on the Rainfall Regime and Its Interannual Variability. International Scholarly Research Notices: Meteorology, 2013, Article ID: 453521.

[65] Nicholson, S. (2005) On the Question of the "Recovery" of the Rains in the West Africa Sahel. Journal of Arid Environments, 63, 615-641. https://doi.org/10.1016/j.jaridenv.2005.03.004

[66] Lebel, T. and Ali, A. (2009) Recent Trends in the Central and Western Sahel Rainfall Regime (1990-2007). Journal of Hydrology, 375, 52-64.

https://doi.org/10.1016/j.jhydrol.2008.11.030

[67] Sanogo, S., Fink, H.A., Omotosho, A.J., Ba, A., Redl, R. and Ermert, V. (2015) Spatio-Temporal Characteristics of the Recent Rainfall Recovery in West Africa. International Journal of Climatology, 35, 4589-4605. https://doi.org/10.1002/joc.4309

[68] Luce, H.C. and Holden, A.Z. (2009) Declining Annual Stream Flow Distributions in the Pacific Northwest United States, 1948-2006. Geophysical Research Letters, 36, L16401. https://doi.org/10.1029/2009GL039407

[69] Nyeko-Ogiramoi, P., Willems, P. and Ngirane-Katashaya, G. (2013) Trend and Variability in Observed Hydrometeorological Extremes in the Lake Victoria Basin. Journal of Hydrology, 489, 56-73. https://doi.org/10.1016/j.jhydrol.2013.02.039 
[70] Olanrewaju, R., Ekiotuassinghan, B. and Akpan, G. (2017) Analysis of Rainfall Pattern and Flood Incidences in Warri Metropolis, Nigeria. Geography, Environment, Sustainability, 10, 83-97. https://doi.org/10.24057/2071-9388-2017-10-4-83-97

[71] Collins, J.M. (2011) Temperature Variability over Africa. Journal of Climate, 24, 3649-3666. https://doi.org/10.1175/2011JCLI3753.1

[72] Hegerl, C.G., Crowley, J.T., Allen, M., Hyde, T.W., Pollack, N.H., Smerdon, J. and Zorita, E. (2007) Detection of Human Influence on a New, Validated 1500-Year Temperature Reconstruction. Journal of Climate, 20, 650-665. https://doi.org/10.1175/JCLI4011.1

[73] Sylla, M.B., Diallo, I. and Pal, J.S. (2013b) West African Monsoon in State-ofthe-Science Regional Climate Models. In: Tarhule, A., Ed., Climate VariabilityRegional and Thematic Patterns, London, 3-36.

[74] Niang, I., Ruppel, O.C., Abdrabo, M.A., Essel, A., Lennard, C., Padgham, J., et al. (2014) Africa. In: Climate Change 2014: Impacts, Adaptation, and Vulnerability: Part B: Regional Aspects, Contribution of Working Group II to the Fifth Assessment Report of the Intergovernmental Panel on Climate Change, Cambridge University Press, Cambridge, 1199-1266.

[75] Brink, A.B. and Eva, H.D. (2009) Monitoring 25 Years of Land Cover Change Dynamics in Africa: A Sample Based Remote Sensing Approach. Applied Geography, 29, 501-512. https://doi.org/10.1016/j.apgeog.2008.10.004

[76] Savané, I., Coulibaly, K.M. and Gioan, P. (2001) Variabilité climatique et ressources en eaux souterraines dans la région semi-montagneuse de Man. Sécheresse, 12, 231-237.

[77] Savané, I., Coulibaly, K.M. and Gioan, P. (2003) Etude comparative de trois méthodes de calcul du coefficient de tarissement des cours d'eau. Sécheresse, 14, 37-42.

[78] Soro, G.E., Noufe, D., Goula, B.T.A. and Srohourou, B. (2016) Trend Analysis for Extreme Rainfall at Sub-Daily and Daily Time Scales in Côte d'Ivoire. Climate, 4, 37. https://doi.org/10.3390/cli4030037

[79] Bao, Z., Zhang, J., Wang, G., Fu, G., He, R. and Yan, X. (2012) Attribution for Decreasing Streamflow of the Haihe River Basin, Northern China: Climate Variability or Human Activities? Journal of Hydrology, 460-461, 117-129. https://doi.org/10.1016/j.jhydrol.2012.06.054

[80] Awotwi, A., Anornu, K.G., Ballard, Q.J., Annor, T. and Forkuo, K.E. (2017) Analysis of Climate and Anthropogenic Impacts on Runoff in the Lower Pra River Basin of Ghana. Heliyon, 3, 12. https://doi.org/10.1016/j.heliyon.2017.e00477

[81] Jaiswal, K.R., Lohani, K.A. and Tiwari, L.H. (2015) Statistical Analysis for Change Detection and Trend Assessment in Climatological Parameters. Environmental Process, 2, 729-749. https://doi.org/10.1007/s40710-015-0105-3

[82] Cecchi, P. (2007) L'eau en partage: Les petits barrages de Côte d'Ivoire. Editions IRD, Paris, 295 p. https://doi.org/10.4000/books.irdeditions.5558 